\title{
Rebalancing The Medical Triad: Justice Blackmun's Contributions To Law And Medicine
}

\author{
Harold Hongju Koh*
}

The American Society of Law and Medicine has chosen to honor Associate Justice Harry A. Blackmun of the United States Supreme Court with its first Presidents' Award for Distinguished Contributions to the Fields of Law and Medicine. It is my task to explain why that honor is so richly deserved.

To me the answer is simple: as much as any other judge in our Nation's two hundred-year constitutional history, Harry Blackmun has shaped and defined our modern conception of the constitutional right to privacy, as well as our developing notions of the scope and limits of medical privacy. ${ }^{1}$ During his twenty-eight years on the federal bench and his seventeen years on the Supreme Court, Justice Blackmun has played a major role in rebalancing what I call "the medical triad" - the triangular relationship among the patient, the doctor and the state, with which this Society's members are so intimately familiar.

What experiences qualified this seemingly ordinary man to play this extraordinary historical role? After reviewing Justice Blackmun's lifelong odyssey through the fields of law and medicine, I would suggest that his career can be divided into four eras: what I will call the era of apprenticeship, the era of authority, the era of

- Associate Professor of Law, Yale Law School; B.A. Harvard 1975; B.A. Oxford 1977; J.D. Harvard 1980; Law Clerk to Justice Harry A. Blackmun, October Term 1981. This essay derives from remarks delivered at the Annual General Meeting of The American Society of Law and Medicine in Boston, Massachusetts on October 23, 1987. I am grateful to Robert Burt and Joseph Goldstein for their insightful comments on an earlier draft and to Marina $\mathbf{L}$. Sheriff of the Yale Law School Class of 1989 for her fine research assistance.

1 By singling out this contribution, I do not mean to slight other areas in which Justice Blackmun has played an equally profound role in shaping the Court's jurisprudence. See, e.g., Koh, Equality with a Human Face: Justice Blackmun and the Equal Protection of Aliens, 8 HAmLine L. Rev. 51 (1985); Kobylka, The Court, Justice Blackmun, and Federalism: A Subtle Movement with Potentially Great Ramifications, 19 Creighton L. Rev. 9 (1985); McDaniel, Public Trials, 8 Hamline L. REv. 127 (1985); Moore, Justice Blackmun's Contributions on the Court: The Commercial Speech and State Taxation Examples, 8 Hamline L. Rev. 29 (1985) 
accountability, and the era of autonomy. As he has grown through each of these eras, Justice Blackmun has increasingly used his judicial position to rebalance the relationship among the patient, the doctor and the state. In majority, concurrence, and dissent, he has pressed the Court to lessen the deference owed to authority figures (whether represented by doctors or the state); to hold institutional authorities accountable for their actions, both to individual physicians and to patients; and to protect both doctors' rights of professional autonomy and patients' rights to individual autonomy.

\section{THE ERA OF APPRENTICESHIP}

Let me begin with Justice Blackmun's "era of apprenticeship" - an era that spanned what for most people would be several professional lifetimes - the sixty-one years he spent as a student, a law clerk, a practicing attorney, and a lower federal court judge, before he assumed his seat on the Supreme Court. During this first era, Justice Blackmun gained his deep and subtle appreciation of the complexities of the medical profession and the moral and ethical challenges that physicians daily face.

While growing up in St. Paul, Minnesota in the 1920's, the son of a grocery and hardware storeowner, the future Supreme Court Justice wanted more than anything else to be a doctor. ${ }^{2}$ But after winning a scholarship to Harvard College, election to Phi Beta Kappa, and earning his B.A. in mathematics summa cum laude, this nonconfrontational man left the sciences for Harvard Law School, forsaking the "honorable and merciful calling" of medicine for the more confrontational profession of law. ${ }^{3}$

His first seventeen years after law school Justice Blackmun spent in Minneapolis, beginning with a 17-month clerkship with Judge John B. Sanborn of the United States Court of Appeals for the Eighth Circuit. Turning to private practice, he became an associate, then a partner at the Dorsey firm, the preeminent Minneapolis law partnership, specializing in the characteristically precise fields of taxation, civil litigation, and trusts and estates. ${ }^{4}$ During those years,

2 See Jenkins, $A$ Candid Talk With Justice Blackmun, N.Y. Times, Feb. 20, 1983, at $\S 6$ (Magazine), 20, 24 (quoting Blackmun, J.)(“" [But] I probably would have been a poor physician.'”).

3 See Blackmun, Remarks at the Commencement Exercises of Mayo Medical School, 55 Mayo Curic Proc. 573, 575 (1980)[hereinafter Mayo Remarks].

4 See Pollett, Harry A. Blackmun, in 5 The Justices of The United States Supreme Court 3, 5 (L. Friedman \& F. Israel eds. 1978). Some commentators argue that Justice Blackmun's mathematics training, coupled with his extended exposure to the "exacting quantitative nature" of tax law, have made him unusually "well-versed in the scientific method." See Schlesinger \& Nesse, Justice Harry Blackmun and Empirical Jurisprudence, 29 AM. U.L. Rev. 405, 406 \& $\mathrm{n} .3$ (1980). Drawing upon this background, the Justice uses empirical data and statistical analysis to add precision to the Court's reasoning and to "assist the court in reaching fair adjudi- 
the Dorsey firm represented, then became general counsel to, the Mayo Clinic and the Mayo Association in Rochester, Minnesota, a continuing representation for which Mr. Blackmun took increasing responsibility. In 1950, the future Justice finally left his firm to become the Mayo Clinic's first resident counsel, spending what he has later called the "happiest decade" of his life, ${ }^{5}$ a "decade of close and intimate association . . . with people of medicine, with the medical mind and medical ways, and with medical education and research ...."6

In 1959, President Eisenhower nominated Justice Blackmun to replace his mentor, Judge Sanborn, on the Eighth Circuit. During the next eleven years, Justice Blackmun's caseload did not often thrust him into legal-medical controversies, although his judicial colleagues routinely deferred to his expertise on medical questions when they arose. ${ }^{7}$ Thus, except for his later, fleeting recollection that most of the malpractice cases that came before him were "resolved in favor of the complaining patient rather than the defending doctor," 8 the Eighth Circuit years offer little insight into Justice Blackmun's evolving medical jurisprudence.

In 1970, after the Senate had rejected both Clement Haynsworth and G. Harrold Carswell as replacements for Justice Abe Fortas, President Nixon turned to Justice Blackmun as a noncontro-

cative results." Id at 406 . For a discussion of two recent cases in which Blackmun understood the import of statistical data and the Court did not, see Appelbaum, The Empirical Jurisprudence of the United States Supreme Court, 13 AM. J. L. \& MED. 335 (1987) (discussing MCCleskey v. Kemp, 107 S. Ct. 1756 (1987); Barefoot v. Estelle, 463 U.S. 880 (1983)).

${ }^{5}$ Jenkins, supra note 2 , at 24 (quoting Blackmun, J.) (" 'It was the happiest decade in the lives of my wife and myself. . . . I was able to have a foot in both camps - law and medicine." ").

${ }^{6}$ Mayo Remarks, supra note 3, at 573. Justice Blackmun later testified that "my experience [at the Mayo Clinic] . . f fortified me, made me somewhat better educated and more knowledgeable in medical fields than I otherwise would be." Harry A. Blackmun: Hearing Before the Senate Judiciary Comm., 91 st Cong., 2d Sess. 41 (1970)(testimony of Blackmun, J.) [hereinafter Confirmation Hearing]. During his Mayo years, the Justice served as a member of the Mayo Section of Administration, and played a major role in founding the Rochester Methodist Hospital, for which he served as a Director, Executive Committee member, and Secretary. During this period, he also authored a number of articles on legal-medical subjects. See, e.g., Blackmun, The Physician and his Estale, 36 MinN. MED. 1033 (October 1953); Blackmun, Legal Problems Attendant Upon the Late Effects of Head Injunies, reprinted in The LATE EFFECTS OF Head Injury (A. Walker, W. Caveness \& M. Critchley, eds. 1969). In honor of the Justice's work as legal counsel, in 1977 the Clinic dedicated the Blackmun Law Library in his honor.

7 See Confirmation Hearing, supra note 6, at 41 (testimony of Judge Blackmun) ("We, of course, have had some malpractice cases [in the Eighth Circuit]. . . . I find myself confronted with the fact that my colleagues say, I am glad you are sitting on this kind of a case because you know medical problems better than I do.").

8 Id. For a thorough survey of Justice Blackmun's Eighth Circuit opinions, see Lay, The Cases of Blackmun, J. on the United States Court of Appeals for the Eighth Circuit, 1959 -1970, 8 HAMLINE L. REv. 2 (1985). 
versial, moderate candidate for the Supreme Court. ${ }^{9}$ The American Bar Association's Standing Committee on the Federal Judiciary, then chaired by no less aggressive an examiner than Lawrence Walsh, now the Iran-Contra Affair special prosecutor, announced that it would investigate Blackmun's qualifications more extensively than those of any prior Supreme Court nominee. ${ }^{10}$ After the ABA Committee concluded that he met "high standards of professional competence, temperament and integrity," "Justice Blackmun won unanimous Supreme Court confirmation. ${ }^{12}$

\section{THE ERA OF AUTHORITY}

Following these apprenticeship years, Justice Blackmun's first three years on the Supreme Court marked a second era, which I call "the era of authority." During this period, Justice Blackmun's vision of the medical triad betrayed an idealistic, almost naive, faith in authority figures: a seemingly reflexive trust of governmental institutions and a casual confidence in the goodness and competence of medical doctors and the medical profession. ${ }^{13}$ One of Justice Blackmun's first opinions for the Court, the 1971 case of Richardson $v$. Perales, ${ }^{14}$ raised the question whether physicians' written medical examination reports, neither signed under oath nor subjected to crossexamination (and therefore hearsay evidence), could be used at a Social Security hearing to deny an injured truckdriver's disability insurance claim. Justice Blackmun ruled that the reports could be so used, based in part on his intuition that judges "cannot . . . ascribe bias to the work of these independent physicians, or any interest on their part in the outcome of the administrative proceeding beyond the professional curiosity a dedicated medical man possesses." ${ }^{15}$ In a biting dissent, Justice Douglas noted that "[o]ne doctor whose word cast this claimant into limbo never saw him, never examined him, never took his vital statistics or saw him try to walk or bend or lift weights."16 Reflecting a skepticism about institutional preroga-

\footnotetext{
9 See L. Kohlmeier, God Save This Honorable Court 173 (1973) (“Blackmun was a political compromise, a noncontroversial judge who had no taste either for resisting the Warren Court's doctrines or pressing forward constitutional rights").

10 See Pollett, supra note 4 , at 4.

11 See Confirmation Hearing, supra note 6, at 12 (letter from the ABA Standing Comm. on the Fed. Judiciary).

12 See Pollett, supra note 4 , at 4.

13 This theme is developed further in Note, The Changing Social Vision of Justice Blackmun, 96 HaRv. L. Rev. 717, 719-22 (1983).

14402 U.S. 389 (1971).

$15 \mathrm{Id}$. at 403.

16 Id. at 413 (Douglas, J., dissenting).
} 
tives that Justice Blackmun himself would later embrace, ${ }^{17}$ Justice Douglas opined that the Department of Health, Education, and Welfare, a "presently powerful federal bureaucracy", was wreaking a "grave injustice ... on an individual" by denying him Social Security benefits, and "cutting . . . corners" with the help of a "stable of defense doctors" working for the government. ${ }^{18}$

Two years later, in Doe v. Bolton, ${ }^{19}$ Justice Blackmun authored the Court's opinion invalidating a Georgia statutory scheme that criminalized abortions in all but a few circumstances. In striking down a provision of the statute that prevented a doctor from performing an abortion without the advance approval of an "abortion committee" made up of hospital staff members, Justice Blackmun chided the state legislature for its "lack of confidence in the integrity of physicians." 20 Justice Blackmun found the committee approval requirement "somewhat degrading to the conscientious physician," and suggested that "[ $t]$ he good physician - despite the presence of rascals in the medical profession, as in all others, we trust that most physicians are 'good' - will have sympathy and understanding for the pregnant patient that probably are not exceeded by those who participate in other areas of professional counseling." 21

In short, Justice Blackmun's early decisions on the Court regarding law and medicine reflected his prior extended contact with talented and responsible physicians and healthy, progressive institutions like the Mayo Clinic. In defining his own judicial role, Justice Blackmun's early instinct was to afford patients' rights no extraordinary protection, assuming that those rights would be amply protected if he trusted and deferred to the expertise and discretion of those professionals and institutions.

\section{THE ERA OF ACCOUNTABILITY}

These early opinions set the stage in 1973 for Roe $v$. Wade,,$^{22}$ the

17 See infra text accompanying notes 29-53. Ironically, in a dissent written more than a decade later, Blackmun would himself question whether psychiatric testimony regarding a defendant's future dangerousness should be admissible in a capital case, given proof that such testimony is wrong two times out of three. See Barefoot v. Estelle, 463 U.S. 880, 916 (1983) (Blackmun, J., dissenting) ("when a person's life is at stake-no matter how heinous his offense-a requirement of greater reliability should prevail. In a capital case, the specious testimony of a psychiatrist, colored in the eyes of an impressionable jury by the inevitable untouchability of a medical specialist's words, equates with death itself."). For further explication of Justice Blackmun's Barefoot dissent, see Appelbaum, supra note 4, and Stone, Justice Blackmun: A Survey of His Decisions in Psychiatry and Law, 13 AM. J. L. \& MED. 291 (1987).

18402 U.S. at 413-14 (Douglas, J., dissenting).

19410 U.S. 179 (1973).

$20 \mathrm{Id}$. at 196.

21 Id. at 196-97.

22410 U.S. 113 (1973). 
decision that would make Justice Blackmun immortal. ${ }^{23}$ That controversial decision not only changed America, it profoundly changed Harry Blackmun. ${ }^{24}$ As those who have read The Brethren are aware, Justice Blackmun agonized over that decision in a manner that some commentators found unseemly. ${ }^{25}$ His search for guidance from medical history and literature drove him to spend two weeks in the Mayo Clinic's medical library, examining prevailing medical and legal attitudes toward abortion, and searching for the origins of the Hippocratic Oath. ${ }^{26}$

Roe $v$. Wade bears many of the earmarks of the eras of apprenticeship and authority, and of Justice Blackmun's early proclivity to trust too fully in the goodness of doctors. Roe held that a woman's right, in consultation with her physician, to choose an abortion is absolute in the first trimester of pregnancy, qualified by the state's interest in protecting the fetus in the second trimester, and subject to state prohibition in the third. Yet much of that opinion's now familiar interest-balancing analysis sounded as if the individual right being protected was that of the doctor and not the patient. ${ }^{27}$ By leav-

${ }^{23}$ Along with Brown v. Board of Education, 347 U.S. 483 (1954), Roe is perhaps the only Supreme Court case decided this century that most Americans know by name. See Hazard. Rising Above Principle, 135 U. PA. L. Rev. 153, 157 (1986) ("The leading case of the 1950's, indeed of the century, is of course Brown $v$. Board of Education. . . That of the 1970's is unquestionably Roe $v$. Wade."). Accord, Sunstein, Lochner's Legacy, 87 Colum. L. REv. 873, 873 (1987)(Roe is a "defining case" in modern constitutional jurisprudence).

${ }^{24}$ See Remarks by H. Blackmun, Franco-American Colloquium on Human Rights 15 (Dec. 19, 1979) [hereinafter Franco-American Colloquium] ("All this has changed my life, in a distinct sense."). See also Neuborne, Blackmun: Intellectual Openness Elicits Needed Respect for the Judicial Process, Nat'l L.J., Feb. 18, 1980, at 18, col. 2, 23, col. 1 ("The emergence of Blackmun as an independent force [on the Court] began, of course, with his controversial opinion in Roe $v$. Wade ... ."); Note, supra note 13, at 725 ("Justice Blackmun's conception of healthy, selfgoverning institutions ... has increasingly given way in the years since Roe to an emphasis on an inquiry that discovers and responds to concrete problems."). For an analysis of Justice Blackmun's decisions in the abortion cases, see Comment, Justice Harry A. Blackmun: The Abortion Decisions, 34 Ark. L. Rev. 276 (1980).

25 See B. Woodward \& S. Armstrong, The Brethren 165-89, 229-40 (1979). By openly agonizing over Roe "not only for myself, but [also] for the Court," Justice Blackmun consciously "disobeyed one suggestion Hugo Black made to me when I first came here. He said, 'Harry, never display agony in public, in an opinion. Never display agony. Never say that this is an agonizing, difficult decision. Always write it as though it's clear as crystal." Jenkins, supra note 2, at 26 (quoting Blackmun, J.).

26 See Franco-American Colloquium, supra note 24, at 14. In his research, Justice Blackmun canvassed, inter alia, the views of the American Medical Association, the American Public Health Association and the American Bar Association. Id.

27 Roe's heavy emphasis on the rights of doctors accounts for much of its unpopularity among legal scholars. See, e.g., Tribe, The Abortion Funding Conundrum: Inalienable Rights, Affirmative Duties, and the Dilemma of Dependence, 99 HaRv. L. REv. 330, 335 (1985) ("“T]he Supreme Court in Roe $v$. Wade spoke as though it were protecting the 'privacy' rights of both the woman and her physician, and indeed at times as though the physician's rights were somehow primary . ... ."); Asaro, The Judicial Portrayal of the Physician in Abortion and Sterilization Decisions: The Use and Abuse of Medical Discretion, 6 HARv. WomEN's L.J. 51, 59 (1983) ("Blackmun's abortion 
ing the state "free to place increasing restrictions on abortion as the period of pregnancy lengthens," Roe sought to "vindicat[e] the right of the physician to administer medical treatment according to his professional judgment up to the points where important state interests provide compelling justifications for intervention." 28

What is important for present purposes, however, is that Roe $v$. Wade expressly protected an individual patient's rights against the state by restricting the freedom of a politically motivated legislature to regulate physicians' discretion to make medical decisions. By so doing, Roe marked Justice Blackmun's transition into a third era of judicial awareness, which I call the era of accountability.

Outsiders can only speculate about why Justice Blackmun began to demand institutional accountability at this time. But part of the explanation must surely lie in the personal agonies he endured both during and after deciding Roe. ${ }^{29}$ The Supreme Court's sprawling docket exposed the Justice to a far broader, and more brutal, slice of life than the Eighth Circuit's had ever done. ${ }^{30}$ The relentless cascade of oral arguments, briefs, and certiorari petitions painted for the Justice a picture of society far less tranquil than the one he had previously known: a society of antagonistic classes, irreconcilable social conflicts, and unchecked personal suffering. ${ }^{31}$ The picture painted was one in which all social institutions are not responsible, healthy, or progressive, and in which a philosophy of judicial deference might amount to judicial abdication in the face of institutional abuse. As an Eighth Circuit Judge, Justice Blackmun had not hesitated to use his judicial role to enforce an individual's constitutional

opinions are as much vindications of the right of the physician to practice medicine as they are feminist 'pro-choice' victories - if not more so.").

28 Roe v. Wade, 410 U.S. at 165-66 (emphasis added). See also id. at 166 ("Up to those points, the abortion decision in all its aspects is inherently, and primarily, a medical decision, and basic responsibility for it must rest with the physician.").

29 See Jenkins, supra note 2, at 26 ("'[Blackmun's] office has received more than 45,000 letters about [Roe $v$. Wade.] (Think of any name; I've been called it in these letters: Butcher of Dachau, murderer, Pontius Pilate, Adolph Hitler'), and he is still ... picketed by anti-abortion groups when he shows up for speaking engagements . ...').

30 See, e.g., Justice Blackmun's dissenting opinion one year before Roe in the decision that temporarily invalidated the death penalty, Furman v. Georgia, 408 U.S. 238, 405 (1972)(Blackmun, J., dissenting) ("Cases such as these provide for me an excruciating agony of the spirit.").

9l See Mayo Remarks, supra note 3, at 573.74 (remarks of Blackmun J.)("The Court is a special place to observe from .... One sees what people-including medical people, their patients, and hospitals-are litigating about today, not only with each other but with their governments-federal, state, and municipal. One gets a sense of their desires and their frustrations, of their hopes and their disappointments, of their profound personal concerns, and of what they regard as important and as crucial. ... We see, in sum, what I think is a constant, seething, economic, domestic, and ethical struggle."). 
guarantees against an overreaching governmental institution. ${ }^{\mathbf{3 2}}$ During the era of accountability, Justice Blackmun began to recast his judicial role more generally toward this orientation, now viewing "the task of the judiciary . . . not [as simply] to defer to institutional discretion, but rather to resolve the conflicts among institutions and individuals" in a way that fully protected individual rights. ${ }^{33}$ Thus, in this third era, which ran through the latter part of the 1970's, Justice Blackmun became noticeably less trustful of the state of hospitals, or indeed, of the Supreme Court itself as paternalistic institutions that invariably have an individual's best interests at heart. ${ }^{34}$ Instead, he began openly to acknowledge that the enormous power of these institutions entails a commensurate measure of accountability and social responsibility.

This new pattern in Justice Blackmun's thinking first became evident in his 1972 decision in Jackson $v$. Indiana,${ }^{35}$ which considered the duties owed by Indiana to Jackson, a 27 year-old retarded deaf mute. After Jackson had been arrested for allegedly stealing nine dollars, two court-appointed psychiatrists found him incapable of understanding the charges against him. That determination led to

32 See, e.g. , Jackson v. Bishop, 404 F.2d 571 (8th Cir. 1968)(Blackmun, J.)(holding that the use of a leather strap to discipline convicts in the Arkansas state penitentiary violated the Cruel and Unusual Punishments Clause of the eighth amendment).

${ }^{33}$ Note, supra note 13, at 722-23. Cf. Burt, Disorder in the Court: The Death Penalty and the Constitution, 85 Mich. L. Rev. 1741, 1803 (1987)(Furman, Roe, and the Nixon Tapes Case arose at a time of "pervasive doubts about the legitimacy of our governmental institutions. These doubts were fueled by the prior decade's convulsive experience of political assassinations, race riots, and an Asian war whose brutality escalated as its intelligibility declined. Because the Justices saw themselves as special guardians of legitimacy in American society, it is not surprising that they should also see a special curative mission for themselves arising from these convulsive challenges to legitimacy.").

34 Compare Wyman v. James, 400 U.S. 309, 323 (1971) (Blackmun, J., for the Court) (depicting welfare caseworker as "not a sleuth but rather, we trust, . . . a friend to one in need") with Lassiter v. Department of Social Servs., 452 U.S. 18, 46 (1981) (Blackmun, J., dissenting) ("When the parent is indigent, lacking in education, and easily intimidated by figures of authority, the imbalance [between the state and an individual whose parental rights it seeks to terminate] may well become insuperable."). My colleague Robert Burt has traced a parallel trend in Justice Blackmun's writings on the death penalty. See Burt, supra note 33. In Professor Burt's view, Justice Blackmun's dissent in Furman, supra note 30, revealed an "obvious struggle between his conscience and his conception of judicial role obligations." See 85 Мıсн. L. REv. at 1757. This probably contributed to his stony silence in the death penalty cases heard during the next decade. In a series of 1983 and 1987 decisions, however, a "newly vocal," Blackmun, id. at 1818, "seemed almost to explode in rhetorical force," id. at 1817, declaring that " $[t]$ he errors and misteps [overlooked by the Court] . . a are too much for me to condone." Barclay v. Florida, 463 U.S. 939, 991 (1983)(Blackmun, J., dissenting). See also McCleskey v. Kemp, 107 S. Ct. 1756, 1794 (1987)(Blackmun, J., dissenting); California v. Brown, 107 S. Ct. 837, 850 (1987)(Blackmun, J., dissenting); California v. Ramos, 463 U.S. 992, 1029 (1983)(Blackmun, J., dissenting); Barefoot v. Estelle, 463 U.S. 880, 916 (1983)(Blackmun, J., dissenting).

35406 U.S. 715 (1972). For further discussion of Jackson, see Stone, supra note 17, and A. Stone, Law, Psychiatry, and Morality 104-06 (1984). 
his commitment for three and one-half years to a state mental facility where no medical treatment was provided and no one knew sign language. ${ }^{36}$ Writing for a unanimous Court, Justice Blackmun held that Jackson's extended commitment to the institution, based solely upon his incapacity to stand trial, denied Jackson his fourteenth amendment rights to due process and equal protection of the laws. ${ }^{37}$ He further emphasized that whenever a state takes on the institutional commitment of any individual for care and treatment, it necessarily assumes the responsibility to do something more than merely warehouse him. "At the least," Justice Blackmun stated, "due process requires that the nature and duration of commitment bear some reasonable relation to the purpose for which the individual is committed." 38

Ten years later, Justice Blackmun elaborated upon this standard in his concurring opinion in Youngberg $v$. Romeo, in which he was joined by Justices Brennan and O'Connor. ${ }^{39}$ Nicholas Romeo, a profoundly retarded 33 year-old, had been involuntarily committed to Pennsylvania's infamous Pennhurst State School and Hospital, where he had been injured more than sixty times. Writing for the Court, Justice Powell concluded that the state was required to provide Romeo minimally adequate or reasonable training, but only to the extent necessary to ensure his safety and allow him freedom from undue restraint. ${ }^{40}$ By so ruling, the majority avoided the much harder question "whether a mentally retarded person, involuntarily committed to a state institution, has some general constitutional right to training per se." ${ }^{1}$ Chief Justice Burger, concurring in the judgment, even called it "frivolous" to suggest that Romeo might have such a federally enforceable right to treatment. ${ }^{42}$ But Justice Blackmun's concurrence in the Court's opinion invoked the Jackson standard to suggest that, once Pennsylvania had chosen to commit Romeo for "care and treatment," it had a constitutional responsibility to provide him treatment as well as care. ${ }^{43}$ Justice Blackmun fur-

\footnotetext{
36 Jackson's attorney argued that "Jackson's commitment under these circumstances amounted to a 'life sentence' without his ever having been convicted of a crime . . ." 406 U.S. at 719 .

37 Id. at 730, 738-39. Justices Powell and Rehnquist took no part in the consideration or decision of the case. Id. at 717 .

38 Id. at 738 (emphasis added).

39457 U.S. 307, 325 (1982)(Blackmun, J., concurring).

40 Id. at 319. For a critique of the Court's Youngberg opinion, see A. STONE, supra note 35, at 126 (" $[\mathrm{H}]$ aving established that right, the Court found some paternalism under the shell of liberty").

41457 U.S. at 318 .

42 Id. at $330 \mathrm{n}$. (Burger, C.J., concurring in the judgment).

43 Id. at 326 (Blackmun, J., concurring) ("If a state court orders a mentally retarded person committed for 'care and treatment,' . . . commitment without any 'treatment' whatsoever
} 
ther suggested that Romeo might also have a constitutional right to that degree of training necessary to preserve those basic self-care skills with which he had entered Pennhurst - for example, the ability to dress himself and to attend to his own personal hygiene. "For many mentally retarded people," Justice Blackmun reasoned, "the difference between the capacity to do things for themselves within an institution and total dependence on the institution for all their needs is as much liberty as they ever will know."

Justice Blackmun subsequently extended his vision of institutional accountability not simply to hospitals and mental institutions, ${ }^{45}$ but also to medical schools. In the Court's famous affirmative action decision, Regents of the University of California $v$. $B a k k e,{ }^{46}$ Justice Blackmun's separate opinion suggested that medical schools bear a special responsibility for diversifying, as well as training, the population of medical doctors. Justice Blackmun noted that until the early 1970 's, less than $2 \%$ of the doctors, lawyers, medical and law students had originated from minority groups and that

would not bear a reasonable relation to the purposes of the person's confinement.") (emphasis in original).

44 Id. at 327 . In arguing that an individual has a right not just to freedom from harm, but also to freedom to flourish and develop, Justice Blackmun espoused a concept of liberty far fuller than the majority's. Compare I. Berlin, Two Concepts of Liberty, in Four Essays on LiBerTy 121 (1979) (elaborating on the distinction between "freedom from" and "freedom to") with Youngberg, 457 U.S. at 327 (Blackmun, J., concurring) ("If a person could demonstrate that he entered a state institution with minimal self-care skills, but lost those skills after commitment because of the State's unreasonable refusal to provide him training, then, it seems to me, he has alleged a loss of liberty quite distinct from-and as serious as-the loss of safety and freedom from unreasonable restraints."). It seems likely that Justice Blackmun's decision to concur in the Court's narrower holding was driven by two strategic motives: to blunt Chief Justice Burger's suggestion that the Court's narrow ruling had somehow implicitly rejected the possibility of a broader constitutional right to treatment, see supra note 42; and to offer a theory that would attract the future support of Justice $O^{\prime}$ Connor, then in her first term on the Court. See text accompanying note 39, supra.

${ }^{45}$ For another example of Justice Blackmun's view of institutional accountability, see O'Bannon v. Town Court Nursing Center, 447 U.S. 773 (1980), in which the Court denied chronically ill elderly nursing home patients a hearing before their nursing home was decertified for Medicare and Medicaid benefits. The Court flatly rejected the residents' claim that their home's decertification would deprive them of life, liberty, and property by exposing them to "transfer trauma"- an alleged increase in morbidity and mortality resulting from their forced relocation from one institution to another. Justice Blackmun refused to "join such a heartless holding," which he argued effectively diminished the state's accountability for its actions. Id. at 803 (Blackmun, J., concurring). He concluded that in fact, decertification could deny the claimants "liberty" and "property" interests. Id. at 791-92. He went on, however, to analyze the state of medical research on "transfer trauma," and found that research too inconclusive to support the patients' claim that such a deprivation had actually occurred. Id. at 804. See also Cohen, Legislative and Educational Alternatives to a Judicial Remedy for the Transfer Trauma Dilemma, 11 AM. J.L. \& MED. 405, 411 (1986) ("The present state of research on transfer trauma justifies Justice Blackmun's conclusion and forecloses any judicial recognition of transfer trauma.").

46438 U.S. 265 (1978). 
three-fourths of our black physicians had trained at only two medical schools; he therefore voted to uphold the University of California's affirmative action program, declaring that, "[i]f ways are not found to remedy that situation the country can never achieve its professed goal of a society that is not race conscious. ... In order to get beyond racism, we must first take account of race. There is no other way." 47

A third institution from which Justice Blackmun began to demand accountability was the Supreme Court itself. In three 1977 rulings, Poelker v. Doe, ${ }^{48}$ Beal v. Doe, ${ }^{49}$ and Maher v. Roe,${ }^{50}$ the Court upheld, over Justice Blackmun's dissent, state decisions to deny indigent women seeking abortions medical reimbursements and public hospital facilities, while simultaneously funding the greater expenses of women who took the medically less risky step of carrying their children to term. ${ }^{51}$ In an intensely personal dissent, Justice Blackmun challenged his colleagues for allowing the states and municipalities to infringe indirectly upon the privacy right that Roe $v$. Wade had said they could not directly restrict. ${ }^{52}$ By so doing, Justice Blackmun suggested, the Court had rendered itself accountable to the rich but not the poor:

For the individual woman concerned, indigent and financially helpless, ... the result is punitive and tragic. Implicit in the Court's holding is the condescension that she may go elsewhere for her abortion. I find that disingenuous and alarming, almost reminiscent of: "Let them eat cake.". . .

[The Court permits a presumed majority to] punitively impres[s] upon a needy minority its own concepts of the socially desirable, the publicly acceptable and the morally sound. ...

There is another world "out there," the existence of which the Court, I suspect, either chooses to ignore or fears to recognize. And so the cancer of poverty will continue to grow. This is a sad day for those who regard the Constitution as a force that would serve justice to all even-

47 Id. at 403,407 (separate opinion of Blackmun, J.)

48432 U.S. 519 (1977).

49432 U.S. 438 (1977).

50432 U.S. 464 (1977).

51 Poelker held that public hospitals that provided publicly financed services for childbirth were not also constitutionally required to perform abortions. Beal and Maher additionally held that states were not required under the Medicaid or Social Security programs to pay the expenses incident to nontherapeutic abortions.

52 See 432 U.S. at 462 (Blackmun, J., dissenting). 
handedly and, in so doing, would better the lot of the poorest among us. ${ }^{53}$

\section{THE ERA OF AUTONOMY}

Although Justice Blackmun's decision in Roe v. Wade won him many public admirers, the heart of his constitutional analysis has proven far more controversial. That analysis, which located the Constitution's protection of a woman's abortion decision in the due process clause of the fourteenth amendment, has been savagely attacked by legal scholars ranging from John Hart Ely to Robert Bork. ${ }^{54}$ Many constitutional law scholars have suggested how Roe could have been more artfully drafted. ${ }^{55}$ But in the end, none of them has put forth a more powerful rationale for the core of that decision than Justice Blackmun himself has subsequently offered.

In a series of opinions that have now stretched into the late 1980's, the fourth and most recent era of his career, we witness a subtle shift in Justice Blackmun's jurisprudence: a movement away from the language of authority and institutional accountability ${ }^{56}$ to the notion that the abortion decisions ultimately rest on the central-

${ }^{53} \mathrm{Id}$. at 462-63. Three years later, Justice Blackmun reiterated his Beal dissent in Harris v. McRae, 448 U.S. 297 (1980), which upheld the constitutionality of the Hyde Amendment, a statute eliminating federal funding for almost all abortions. See id. at 348 (Blackmun, J., dissenting). For critiques of Harris, see Tribe, supra note 27, at 336-40; Perry, Why the Supreme Court Was Plainly Wrong in the Hyde Amendment Case: A Brief Comment on Harris v. McRae, 32 Stan. L. Rev. 1113 (1980).

Three years after Harris, in Planned Parenthood Ass'n v. Ashcroft, 462 U.S. 476 (1983), Blackmun again displayed his sensitivity to the concerns of indigent women seeking abortions. Dissenting from that portion of the majority's decision upholding a statutory requirement that abortions be followed by submission of tissue samples to a board-eligible or certified pathologist, Blackmun argued that mandatory resort to a pathologist did not further important state-related health concerns and could increase the cost of a first-trimester abortion by as much as $\$ 40$. See id. at 497 (Blackmun, J., concurring in part and dissenting in part) ("Although this increase may seem insignificant from the Court's comfortable perspective, I cannot say that it is equally insignificant to every woman seeking an abortion.").

54 See Ely, The Wages of Crying Wolf: A Comment on Roe v. Wade, 82 Yale L.J. 920 (1973); Hearings Before the Subcomm. on Separation of Powers of the Senate Judiciary Comm., 97th Cong., 1st Sess., June 10, 198I, at 310 (Testimony of Robert Bork)("I am convinced, as I think most legal scholars are, that Roe $v$. Wade is itself, an unconstitutional decision, a serious and wholly unjustifiable judicial usurpation of state legislative authority.").

55 See, e.g., Freund, Storms Over the Supreme Court, 69 A.B.A.J. 1474, 1480 (1983); Regan, Rewriting Roe v. Wade, 77 Mich. L. Rev. 1569 (1979); Karst, Foreword: Equal Citizenship Under the Fourteenth Amendment, 91 Harv. L. Rev. 1, 53-59 (1977); Perry, Abortion, the Public Morals, and the Police Power: The Ethical Function of Substantive Due Process, 23 UCLA L. Rev. 689 (1976); Heymann \& Barzelay, The Forest and the Trees: Roe v. Wade And Its Critics, 53 B.U.L. Rev. 765 (1973); Tribe, Foreword, Toward a Model of Roles in the Due Process of Life and Law, 87 Harv. L. Rev. 1 (1973).

56 By highlighting this rhetorical shift, I do not mean to suggest that Justice Blackmun has abandoned the emphasis upon institutional accountability that animated his decisionmaking throughout the late 1970's. For a discussion of how the Justice has continued in recent opin- 
ity of autonomy: primarily the individual autonomy of the patient to make intimate decisions uncoerced by the state and, secondarily, the professional autonomy of the physician to counsel the patient in the making of such fateful decisions. In this fourth era, the era of autonomy, Justice Blackmun's opinions have begun to sketch an evolving notion of medical privacy, based upon the patient's individual autonomy, as supplemented by the doctor's professional autonomy. ${ }^{57}$

I have already suggested that Justice Blackmun's solicitude for the professional autonomy of doctors was evident even in earlier eras. In the various abortion decisions that followed in the wake of Roe $v$. Wade, Justice Blackmun had steadfastly protected the rights of doctors to engage in responsible exercises of medical judgment. Writing for the Court in Planned Parenthood v. Danforth, ${ }^{58}$ Justice Blackmun had upheld Missouri's informed consent statute in abortion cases, while warning against other informed consent statutes that might "confine the attending physician in an undesired and uncomfortable straitjacket." ${ }^{59}$ Similarly, in Colautti $v$. Franklin, ${ }^{60}$ Justice Blackmun had struck down as unconstitutionally vague a Pennsylvania criminal statute that failed to give physicians clear notice of what medical activities they could permissibly undertake when performing constitutionally protected abortions. ${ }^{61}$ But what

ions "to invoke and to act on images of abuse by institutions, structural harm, and individual suffering," see Note, supra note 13, at 725-31.

57 For more detailed discussions of evolving notions of patient and professional autonomy, see Baron, On Knowing One's Chains and Decking Them With Flowers: Limits on Patient Autonomy in "The Silent World of Doctor and Patient," 9 W.N. ENG. L. REv. 31 (1987); Johnson, Sequential Domination, Autonomy and Living Wills, 9 W.N. EnG. L. Rev. 113 (1987); and Spiegel, Lawyers and Professional Autonomy: Reflections on Corporate Lawyering and the Doctrine of Informed Consent, 9 W.N. EnG. L. Rev. 139 (1987).

58428 U.S. 52 (1976).

59 Id. at 67 n.8.

60439 U.S. 379 (1979).

61 In Justice Blackmun's view, the statute too narrowly limited a doctor's medical discretion to make determinations regarding the viability of a fetus. He declared:

Because [the point of viability] may differ with each pregnancy, neither the legislature nor the courts may proclaim one of the elements entering into the ascertainment of viability - be it weeks of gestation or fetal weight or any other single factor - as the determinant of when the State has a compelling interest in the life or health of the fetus....

We reaffirm . . . that "the determination of whether a particular fetus is viable is, and must be, a matter for the judgment of the responsible attending physician." Id. at 388-89, 396 (citations omitted).

In Planned Parenthood Ass'n v. Ashcroft, 462 U.S. 476 (1983), discussed in supra note 53, Justice Blackmun expressed similar dissatisfaction with a statutory requirement that likewise constrained physicians' discretion. A Missouri statute required the attendance of a second physician at all postviability abortions. Noting that Missouri did not require a second physician to attend any other medical procedure, Justice Blackmun argued that:

[c]onsultation and teamwork are fundamental in medical practice, but in an operating room a patient's life or health may depend on split-second decisions by the physi- 
distinguishes Justice Blackmun's modern opinions in the era of autonomy from these earlier rulings is that they no longer champion a physician's discretion for its own sake. Rather, they protect a doctor's exercise of his or her medical judgment in order to maximize the patient's ability to exercise his or her own autonomy. ${ }^{62}$ In the era of autonomy, the primary right that Justice Blackmun would protect is the right of the patient, regardless of age or marital status, ${ }^{63}$ to make intimate personal decisions without being coerced by the state or by the doctor. In short, in the era of authority, when Justice Blackmun wrote Roe $v$. Wade, he saw the question as "whether the woman and her doctor, rather than an agency of government, should have the authority to make the abortion decision at various stages of pregnancy." 64 In his new era of individual and professional autonomy, Justice Blackmun would no longer grant the doctor final choice, but would nevertheless shield the doctor's discretion from state interference in order to ensure that the patient - in whose hands the ultimate moral judgment rests - will receive the maximum advice and consultation.

Two opinions issued in 1986, Justice Blackmun's majority opinion in Thornburgh v. American College of Obstetricians and Gynecologists ${ }^{65}$

cian. If responsibility and control must be shared between two physicians with the lines of authority unclear, precious moments may be lost to the detriment of both woman and child.

462 U.S. at 503 n. 10 (Blackmun, J., concurring in part and dissenting in part).

62 "To acknowledge that 'the patient's right of self-decision shapes the boundaries of the [authorities'] duty to reveal [medical risks]' requires not that the patient's choice be an intelligent, informed and unemotionally determined decision, but that it be the patient's choice and that the authorities, of regard for him as a human being, honor that choice . ..."Goldstein, For Harold Lasswell: Some Reflections on Human Dignity, Entrapment, Informed Consent, and the Plea Bargain, 84 YALE L.J. 683, 695 (1975) (citations omitted)(emphasis in original). For a discussion of how authorities may reconcile legal requirements of informed consent with notions of deference to the dignity of the citizen as a human being, see id. at 692-93.

63 Writing for the Court in Planned Parenthood of Mo. v. Danforth, 428 U.S. 52 (1976), Blackmun struck down various Missouri statutory provisions restricting an individual woman's access to abortion, specifically those requiring spousal consent or parental consent for a minor. See id. at 67-75. Yet even after Danforth, the constitutionality of parental consent statutes remains controversial. Compare Bellotti v. Baird, 443 U.S. 622 (1979)(plurality opinion)(invalidating Massachusetts parental consent statute for abortion cases but stating that an appropriately structured judicial-consent requirement would be constitutional) with Ashcroft, 462 U.S. at 503-04 (Blackmun, J., dissenting in part) (continuing to assert that neither parents nor judges may veto a pregnant minor female's decision to have an abortion). Last Term, the Court divided equally on the question whether Illinois could constitutionally require an unmarried minor to wait twenty-four hours before having an abortion, so that her parents could be notified. Under the Illinois law, a doctor who performs an abortion on a minor without notifying her parents, or who fails to observe the twenty-four hour statutory waiting period, can be subjected to criminal prosecution. See Hartigan v. Zbaraz, $108 \mathrm{~S}$. Ct. 479 (1987), aff' $g$ by an equally divided court, 763 F.2d 1532 (7th Cir. 1985).

64 Tribe, supra note 55, at 11 (emphasis added).

65106 S. Ct. 2169 (1986). 
and his dissent in Bowers v. Hardwick, ${ }^{66}$ illustrate Justice Blackmun's deepened appreciation of both personal and professional autonomy. In Thornburgh, a group of plaintiffs that included the American College of Obstetricians and Gynecologists, individual physicians (including many who performed abortions), and abortion counselors brought a wide ranging challenge to the 1982 Pennsylvania Abortion Control Act. Striking down six provisions of that statute, Justice Blackmun concluded that they impermissibly attempted to deter a woman from making what he called "an intensely private" decision $^{67}$ - "a decision that, with her physician, is hers to make." 68 In striking down provisions that required doctors to read printed warnings to patients, Justice Blackmun held that the Commonwealth could not "wedge [its] message discouraging abortion into the privacy of the informed-consent dialogue between the woman and her physician." 69 Nor could Pennsylvania impose "state medicine .. . upon the woman," "officially structure ... the dialogue between the woman and her physician," or make the doctor an "agent of the State" by requiring the physician to offer the patient potentially irrelevant information. ${ }^{70}$ He concluded by saying:

Our cases long have recognized that the Constitution embodies a promise that a certain private sphere of individual liberty will be kept largely beyond the reach of government. That promise extends to women as well as to men. Few decisions are more personal and intimate, more properly private, or more basic to individual dignity and autonomy, than a woman's decision - with the guidance of her physician and within the limits specified in Roe - whether to end her pregnancy. A woman's right to make that choice freely is fundamental. Any other result, in our view, would protect inadequately a central part of the sphere of liberty that our law guarantees equally to all. ${ }^{71}$

66106 S. Ct. 2841 (1986).

$67106 \mathrm{~S}$. Ct. at 2181.

68 Id. at 2178 (emphasis added). Although Justice Blackmun has perhaps felt institutionally constrained from formally repudiating Roe's reliance on the rights of both the doctor and the patient, his Thomburgh opinion reflects a considered determination to shift Roe's emphasis toward the autonomy of the individual, and not the doctor. That shift of emphasis makes clear that the decision ultimately being protected rests in the hands of the patient, not the physician. See id. ("In the years since . . Roe, States and municipalities have adopted a number of measures seemingly designed to prevent a woman, with the advice of her physician, from exercising her freedom of choice. ... [T] The constitutional principles that led this Court to its decisions in 1973 still provide the compelling reason for recognizing the constitutional dimensions of a woman's right to decide whether to end her pregnancy.") (emphasis added).

69 Id. at 2179.

$70 \mathrm{Id}$. at 2180 .

${ }^{71}$ Id. at 2184-85 (emphasis added)(citations omitted). 
Ironically, Justice Blackmun's most eloquent defense of rights of individual autonomy and privacy arose not in a legal-medical context, but in a dissent from a case that had no direct medical overtones. In Bowers v. Hardwick, ${ }^{72}$ a five-Justice majority upheld a Georgia sodomy statute, stating the issue as "whether the Federal Constitution confers a fundamental right upon homosexuals to engage in sodomy and hence invalidates the laws of the many States that still make such conduct illegal and have done so for a very long time."73 Having cast the issue that way, it is hardly surprising that the majority found no such right, reasoning that homosexual activity is totally unconnected with family, marriage and procreation those areas that it found the Court had previously protected. ${ }^{74}$ In a dissent that one commentator has called "an opinion of lyric power, . . . even literary beauty [that] will cement Justice Blackmun's claim to being a justice of sensitivity and deep constitutional understanding," 75 Justice Blackmun made it clear that he believed those earlier decisions to rest on a broader ground: namely, an individual's right to dignity and autonomy in the making of intimate personal decisions.

Rather than paraphrase his words, I will let Justice Blackmun speak for himself:

This case is no more about "a fundamental right to engage in homosexual sodomy," as the Court purports to declare, than Stanley $v$. Georgia was about a fundamental right to watch obscene movies, or Katz $v$. United States was about a fundamental right to place interstate bets from a telephone booth. Rather, this case is about "the most comprehensive of rights and the right most valued by civilized men," namely, "the right to be let alone." . . .

The statute at issue denies individuals the right to de-

72106 S. Ct. 2841 (1986) (Blackmun, J., dissenting).

${ }^{73}$ Id. at 2843.

74 Id. at 2844. In fact, as Professor Tribe has recognized, the Court's prior decisions in Griswold v. Connecticut, 381 U.S. 479 (1965); Eisenstadt v. Baird, 405 U.S. 438 (1972); and Carey v. Population Servs. Int'l, 431 U.S. 678 (1977), had "protected the decision to engage in sex without bearing or begetting a child. These holdings thus mandated heightened scrutiny not of state restrictions on procreative sex, but of restrictions on recreational or expressional sex-sex solely as a facet of associational intimacy-whether between spouses or between unmarried lovers. The Hardwick majority nevertheless treated [these] prior decisions upholding access to contraceptives as if they involved the right to buy and use a particular pharmaceutical product, rather than the right to engage in sexual intimacy as such." $L$. Tribe, American Constitutional Law 1423 (2d ed. 1988)(emphasis in original).

75 Velvel, Zeus Didn't Nod: There's Hope After All for Justice Blackmun, Nat'l L.J., Oct. 6, 1986, at 13, col. 2 . 
cide for themselves whether to engage in particular forms of private, consensual sexual activity. ... .

The case before us implicates both the decisional and the spatial aspects of the right to privacy....

The Court concludes today that none of our prior cases dealing with various decisions that individuals are entitled to make free of governmental interference "bears any resemblance to the claimed constitutional right of homosexuals to engage in acts of sodomy that is asserted in this case." ... [But] [w]e protect [the] rights [at issue in those earlier decisions] not because they contribute, in some direct and material way, to the general public welfare, but because they form so central a part of an individual's life. "[T]he concept of privacy embodies the 'moral fact that a person belongs to himself and not others nor to society as a whole." 'And so we protect the decision whether to marry precisely because marriage "is an association that promotes a way of life, not causes; a harmony in living, not political faiths; a bilateral loyalty, not commercial or social projects." We protect the decision whether to have a child because parenthood alters so dramatically an individual's self-definition, not because of demographic considerations or the Bible's command to be fruitful and multiply. And we protect the family because it contributes so powerfully to the happiness of individuals, not because of a preference for stereotypical households. . . .

Only the most willful blindness could obscure the fact that sexual intimacy is "a sensitive, key relationship of human existence, central to family life, community welfare, and the development of human personality." The fact that individuals define themselves in a significant way through their intimate sexual relationships with others suggests, in a Nation as diverse as ours, that there may be many "right" ways of conducting those relationships, and that much of the richness of a relationship will come from the freedom an individual has to choose the form and nature of these intensely personal bonds. . . .

[A] necessary corollary of giving individuals freedom to choose how to conduct their lives is acceptance of the fact that different individuals will make different choices. ...

It is precisely because the issue raised by this case touches the heart of what makes individuals what they are 
that we should be especially sensitive to the rights of those whose choices upset the majority. . . .

[D]epriving individuals of the right to choose for themselves how to conduct their intimate relationships poses a far greater threat to the values most deeply rooted in our Nation's history than tolerance of nonconformity could ever do. Because I think the Court today betrays those values, I dissent. ${ }^{76}$

In short, in Bowers, Justice Blackmun argued that the Constitution grants individuals a protected realm of private, intimate, personal decisions. The courts have chosen to protect these decisions not merely because they are associated with respected institutions, such as the family and marriage, but because they are central to an individual's self-definition, sense of bodily well-being, and happiness. This decisional aspect of the constitutional right to privacy, Justice Blackmun would argue, is broad enough to encompass an emerging notion of medical privacy, namely, an individual's right, with the counseling and expertise of an independent doctor, to make certain intensely private medical decisions.

In sum, Harry Blackmun has traveled a long way from his era of apprenticeship to his era of autonomy. After listening and deliberating, he has reassessed and rebalanced the triadic relationship among the patient, the doctor and the state. Over time, he has come to view his judicial role as requiring him not simply to defer to institutional prerogatives, but to hold governmental institutions accountable for their actions, and to empower doctors against the state and individuals vis-à-vis both doctors and the state. Some have argued that this reevaluation reflects Justice Blackmun's ideological shift leftward; others claim that Justice Blackmun has simply resisted the rightward movement of the rest of the Court. ${ }^{77}$ But perhaps the most simple and satisfying explanation is the Justice's own: "[j]udgment, judgment, judgment. It grows by experience and it grows by learning." 78 More than 20 years ago, he wrote, "[w]e must appreciate the practical aspects [of judging]. Judicial attitudes change. ... We progress, we hope, in legal and even in constitutional interpretation. As in medicine ... so in law, although more slowly, there is constant movement. We should be aware of this, anticipate it, and not resent it. We would not wish the situation to

76106 S. Ct. at 2848, 2851-52, 2854, 2856 (Blackmun, J., dissenting) (emphasis in original) (citations omitted).

77 Compare Note, supra note 13, at 717 n.6 (charting Justice Blackmun's leftward movement) with Barbash \& Kamen, Blackmun Says 'Weary' Court Is Shifting Right, Wash. Post, Sept. 20, 1984, at Al, col. 3 .

78 Blackmun, Some Goals for Legal Education, 1 OHı N.L. REv. 403, 408 (1974). 
be otherwise."79

\section{CONCLUSION}

If you will permit an international lawyer one final observation: to a degree unmatched by other nations, our constitutional system has entrusted the job of adapting the Constitution to changing times not to the President or Congress, or to the unwieldy constitutional convention process, but to unelected federal judges. As the career of now-retired Associate Justice Lewis Powell revealed, our American system of making constitutional law gives Supreme Court Justices enormous leeway to interpret cryptic constitutional texts, so that a single Justice wields not only the de facto power to amend the Constitution, but also the literal power of life and death. ${ }^{80}$

America's judicial heroes have traditionally been bold, outgoing, larger-than-life men - Oliver Wendell Holmes, Felix Frankfurter, William O. Douglas - intellectually gifted and arrogant men charged with a political vision and blessed with an effortless pen and a biting tongue. Harry Blackmun, the most modest and self-effacing of men, hardly fits this stereotype. ${ }^{81}$ But as the recent Supreme Court confirmation hearings of Robert Bork have revealed, this old image of the judicial hero no longer attracts everyone. For many, a slashing judicial style now matters less than a thoughtful judicial attitude; a broad ideological vision counts less than open-minded and fundamental fairness. A judge's technical brilliance proves less important than his or her careful attention to precedent and abiding sensitivity to the rights of the weak.

Justice Blackmun's career has been full of ironies. As a lawyer, he has had far more influence on the medical profession than he ever would have had as a doctor. Shy by nature and conservative by temperament, his sense of judicial duty has made him increasingly bold in style and liberal in outlook. Because he has authored decisions protecting a constitutional zone of privacy for others, he and his wife have been forced to sacrifice much of their own jealously guarded private life. And perhaps the greatest irony of all, by consciously avoiding the traditional archetype of the American judicial

${ }^{79}$ Blackmun, Allowance of In Forma Pauperis Appeals in $\$ 2255$ and Habeas Corpus Cases, 43 F.R.D. 343, 359 (1967).

${ }^{80}$ For an extended analysis of Justice Powell's role and rationales as the Burger Court's swing vote, see Kahn, The Court, the Community and the Judicial Balance: The Jurisprudence of Justice Powell, 97 YaLE L.J. 1 (1987).

${ }^{81}$ Cf. Pressman, Blackmun Calls for Faith During Tumultuous Times, L.A. Dally J., Jan. 29, 1980, at 1 , col. $6 \& 9$ (quoting Blackmun, J.) ("It is a time to be aware of our basic fallibility. It is a time when one should recognize now and forever that there is no room in the law for arrogance."). 
hero, he has unconsciously fostered a new image of judicial heroism to guide us into the next 200 years of our constitutional history: the image of a thoughtful man unafraid to show his anguish; a judge who does his own work; who is open-minded and willing to change; who demonstrates a capacity for intellectual growth; and who commands respect for the process of judging by his sheer dedication and integrity of character. ${ }^{82}$ This seemingly ordinary man's extraordinary career has redefined our model of judicial courage and character. It is because of that career that this Society should be proud to present Harry Blackmun its first Presidents' Award for Distinguished Contributions to Law and Medicine.

82 For a prediction that this would happen, see Neuborne, supra note 24 , at 18 , cols. $2-3$ ("One important measure of judicial quality is the ability to generate respect for the processes of adjudication even from persons who disagree with the result. . . . Justice] Blackmun has ... a significant role [to play on the Supreme Court] as a justice capable of eliciting respect for the process of judging."). 